13. Malecka-Griggs B, Kennedy C, Ross B. Microbial burdens in disposable and nondisposable ventilator circuits used for 24 and 48 hours in intensive care units. J Clin Microbiol $1989 ; 27: 495-503$.

14. Cadwallader HL, Bradley CR, Ayliffe GAJ. Bacterial contamination and frequency of changing ventilator circuits. $J$ Hosp Infect $1990 ; 15: 54-72$.

15. Garner JS, Jarvis WR, Emori TG, Horan TC, Hughes JM. CDC definitions for nosocomial infections, 1988. Am $J$ Infect Control 1988:16:128-140.

16. Emori TG, Culver DH, Horan TC, et al. National Nosocomial Infections Surveillance System (NNIS): description of surveillance methods. Am J Infect Control 1991;19:19-35.

17. National Nosocomial Infections Surveillance (NNIS) System. Nosocomial infection rates for interhospital comparison: limitations and possible solutions. Infect Control Hosp Epidemiol 1991:12:609-621.

18. Lareau SC, Ryan KJ, Diener CF. The relationship between frequency of ventilator circuit changes and infectious hazard. Am Rev Respir Dis 1978;118:493-496.

19. Craven DE, Kunches LM, Kilinsky V, Lichtenberg DA, Make $\mathrm{BJ}, \mathrm{McCabe}$ WR. Risk factors for pneumonia and fatality in patients receiving continuous mechanical ventilation. Am R ev Respir Dis 1986;133:792-796.
20. Dreyfuss D, Djedaini K, Weber P, et al. Prospective study of nosocomial pneumonia and of patient and circuit colonization during mechanical ventilation with circuit changes every 48 hours versus no change. Am Rev Respir Dis 1991;143:738-743.

21. Boher M, Lohse S, Glasby C, Friel M, Quan S, Mandel R. Impact of 7-day ventilator tubing changes on nosocomial lower respiratory tract infections. 19th Annual Educational and International Conference of the Association for Practitioners in Infection Control; June 1992; San Francisco, CA Abstract 63.

22. Mermel L, Eveloff S, Short K, et al. The risk of pneumonia associated with use of heated wire versus conventional ventilator circuits-a prospective trial. Fourth Annual Meeting of the Society for Hospital Epidemiology of America; March 1994; New Orleans, LA. Abstract M44.

23. Kotilainen HR, Keroack MA Cost analysis and clinical impact of weekly ventilator circuit changes in intensive care unit patients. Fourth Annual Meeting of the Society for Hospital Epidemiology of America: March 1994; New Orleans, LA Abstract M45.

24. Edwards J, Gaynes R, Culver D, National Nosocomial Infections Surveillance System. Temporal trends in deviceassociated infection rates in intensive care units in the United States. Third Annual Meeting of the Society for Hospital Epidemiology of America; April 1993; Chicago, IL. Abstract 19.

\title{
CDC Funds Surveillance Programs
}

\section{Edited by Gina Pugliese, R N, M S Medical News E ditor}

A cooperative agreement between CDC and selected local agencies was initiated in September 1995 to support 10 Epidemiology and Laboratory Surveillance and Response Programs. The programs are funded from resources allocated to CDC's National Center for Infectious Disease for 1995 to begin implementation of the emerging infectious disease plan. This program will help state and local health agencies to maintain and strengthen public health surveillance and response for infectious diseases.

Thirty-seven applications were approved for funding, and an objec- tive review panel recommended that $\$ 1,960,000$ be awarded to the top 10 scoring applicants: Colorado, Florida, Georgia, Kansas, Los Angeles County, Massachusetts, New Jersey, New York City, Washington, and West Virginia.

FROM: NCID Funds New Cooperative Agreement. $C D C / N C I D$ Focus.1995;5:1. 